\title{
Performance of thermophilic anaerobic digesters using inoculum mixes with enhanced methanogenic diversity
}

Short title: Thermophilic anaerobic digestion with methanogen enhanced inocula

\author{
Sophia Ghanimeh ${ }^{1,2}$, Mutasem El Fadel ${ }^{1 *}$ and Pascal E. Saikaly ${ }^{3}$ \\ ${ }^{1}$ Department of Civil and Environmental Engineering, American University of Beirut \\ ${ }^{2}$ Department of Civil and Environmental Engineering, Notre Dame University-Louaize \\ ${ }^{3}$ Water Desalination and Reuse Research Center, KAUST, Thuwal, KSA \\ ${ }^{*}$ Corresponding author: E-mail: mfadel@aub.edu.lb
}

\begin{abstract}
BACKGROUND: Reportedly, various mixes of seeds were quasi-randomly selected to startup anaerobic digesters. In contrast, this study examines the impact of inoculating thermophilic anaerobic digesters with a designed mix of non-acclimated seeds based on their methanogen composition, using Quantitative Polymerase Chain Reaction (QPCR) of 16S rRNA gene, to achieve high abundance and diversity of methanogens.

RESULTS: Based on QPCR results, two seed mixes were selected to inoculate two anaerobic digesters: digester (A) was inoculated with a control seed consisting of digestate, manure, and activated sludge; and digester (B) was inoculated with a further methanogen-enriched seed consisting of the control seed with added compost and leachate. Both seed combinations yielded a balanced microflora that is able to achieve a successful startup. However, upon reaching steady state, digester B exhibited lower propionate levels, resulting in lower VFA concentration and increased buffering capacity, indicating greater stability. Acetotrophs and hydrogenotrophs were dominated by Methanosarcinaceae and Methanobacteriales, respectively, in both digesters, exhibiting an average ratio of 66 -to- $34 \%$ in A and 76 -to- $24 \%$ in B during steady state.
\end{abstract}

This article has been accepted for publication and undergone full peer review but has not been through the copyediting, typesetting, pagination and proofreading process, which may lead to differences between this version and the Version of Record. Please cite this article as doi: $10.1002 /$ jctb.5341

This article is protected by copyright. All rights reserved. 
CONCLUSION: The inoculation strategy in digester B resulted in improved stability, lower propionate concentration and $10 \%$ higher relative abundance of acetotrophs.

Keywords: Anaerobic digestion; Biomass; Waste treatment and minimization

\section{INTRODUCTION}

Anaerobic digestion (AD) systems operating under thermophilic conditions (55$60^{\circ} \mathrm{C}$ ) have the unique feature of producing hygienic fertilizers with greater process efficiency. However, to date, the market penetration of thermophilic AD has been hindered by operational difficulties and instability challenges invariably associated with a poor startup and a lack of acclimated inoculum. As such, readily available seeds have been suggested to enhance the startup of anaerobic digesters including, but not limited to, primary and secondary sludge, waste activated sludge (WAS), wastewater, landfill leachate, municipal compost, rumen and raw manure. ${ }^{1}$

Several studies examined the importance of the appropriate source and type of

seed. ${ }^{2,3,4}$ Yet, the optimum inoculum depends greatly on the substrate composition and operating conditions. Cordoba et al. ${ }^{1}$ reported that stabilized swine wastewater and sewage sludge are more effective inoculation sources than rumen, as they can lead to improved solids removal and methane generation in mesophilic AD of swine wastewater. Forster-Carneiro et al. ${ }^{4}$ tested six inoculum sources (corn silage, digested waste with rice hulls, cattle excrement, swine excrement, and a mix of swine excrement and sludge) and concluded that the digested sludge from a mesophilic anaerobic digester, was the best inoculum source for thermophilic AD of the Organic Fraction of Municipal Solid Waste (OFMSW). In addition, Costa et al. ${ }^{2}$ showed that the operational mode of the seeding system (i.e. suspended vs. granular) can also affect the

This article is protected by copyright. All rights reserved. 
inoculated digester. They showed that the optimum inoculum mix for mesophilic AD of Ulexeuropaeus, a widely invasive plant, consists of 55\% anaerobic granular sludge to $45 \%$ anaerobic suspended sludge. Furthermore, Moset et al. ${ }^{3}$ showed that the substrate on which the seeding system feeds can also have a significant impact. Anaerobic systems fed with more than $70 \%$ animal manure provided optimum inocula, that can result in the highest methane production, for thermophilic $\mathrm{AD}$ of wheat straw, whole crop maize, cattle manure, grass and cellulose. Similarly, Gu et al. ${ }^{5}$ showed that seeds from manure digesters are better inocula for the mesophilic AD of rice straw, compared to seeds from sludge digesters. Also, digesters treating food leftovers can provide a better seed, leading to a higher methane yield, compared to seeds from digesters treating wastewater sludge. ${ }^{6}$

Other studies considered combining more than one source/type of seed to reach an optimum mix with a diverse microbial composition. In this context, using manure alone to inoculate thermophilic AD of the OFMSW resulted in high propionate accumulation $^{7}$ while enriching cattle manure with soil and WAS resulted in a noticeably faster startup of thermophilic digesters than those seeded with manure only. ${ }^{8}$ Alternatively, several types of manure, e.g. horse, dog and sheep feces, were mixed to enhance the anaerobic "cometabolism" of fruit and vegetable waste. ${ }^{9}$ Other sources, less studied than animal manure, that have the potential of enriching the initial seed include municipal waste compost and landfill leachate. In fact, municipal waste compost can host thermophilic methanogens in anoxic niches, at a level of $\sim 2 \times 10^{7}$ to $10^{9} \mathrm{~g}^{-1}$ dry weight. Methanogens in 6-week-old samples of biowaste compost at $60^{\circ} \mathrm{C}$ were associated with the hydrogenotrophic methanogen Methanothermobacter spp. (86\%) and the acetoclastic methanogen Methanosarcina thermophila spp. (14\%). ${ }^{10,11}$ The addition of the waste compost to a mesophilic digester, inoculated with manure and 
sewage sludge, induced a shift in the methanogenic community toward hydrogenotrophs and reduced the required hydraulic retention time. ${ }^{12}$

Similarly, it has been shown that methanogens constitute $2 \%$ of the total microbial community in leachate from a solid waste landfill and that dominant clones in landfills are close relatives to thermophilic hydrogenotrophic methanogens. ${ }^{13,14}$ In addition, leachate can be used for its ability to enhance cellulose hydrolysis. ${ }^{15}$ Yet, leachate is reported to be a less efficient inoculum, compared to anaerobic sludge for mesophilic AD of solid agro-industrial waste. ${ }^{16}$

While several studies aimed at providing a random mix of non-acclimated seeds to optimize the performance of thermophilic anaerobic digesters, this study attempts for the first time to rationally design a mix of non-acclimated seeds based on their methanogen composition, using Quantitative Polymerase Chain Reaction (QPCR) of 16S rRNA gene, to achieve high abundance and diversity of methanogens. To the best of our knowledge, the impact of adding concomitantly municipal compost and landfill leachate on the startup and steady-state operation of thermophilic AD of the OFMSW has not been reported previously. The digesters were operated in a semi-continuous feeding mode for 250 days to evaluate the seed impacts on the performance, stability, and methanogenic composition during startup and steady-state operation.

\section{MATERIALS AND METHODS}

\section{Waste collection and characterization}

The OFMSW was collected from local households and food markets then ground and homogenized using a commercial food processor. The waste was prepared in one large batch, stored at $-20{ }^{\circ} \mathrm{C}$ in small containers, and used for feeding throughout the experimental program to minimize fluctuations in the feed characteristics. Three samples were collected from the waste batch and analyzed for particulate and soluble

This article is protected by copyright. All rights reserved. 
compounds prior to storage. Average values are reported in Table 1. The required amount of waste was thawed before feeding to avoid aerobic degradation, which might alter the feedstock composition.

\section{Insert Table 1: Feed characteristics}

\section{System set up and operation}

Two anaerobic reactors (Bioflo 110, New Brunswick Scientific Co.), of 14 L capacity and $9 \mathrm{~L}$ working volume, were operated at $55^{\circ} \mathrm{C}$ and were continuously mixed with an internal impeller at $80 \mathrm{rpm}$ - a stirring speed that was proven adequate for the stable operation of thermophilic AD of OFMSW. ${ }^{7,17}$ The Organic Loading Rate (OLR) was step-increased by $20-35 \%$ every three weeks, from 0.8 to $2.4 \mathrm{gVS} / \mathrm{L}$.d, with no observed accumulation of VFAs. The Hydraulic Retention Time (HRT) was maintained at $\sim 45$ days till day 51 of the experimental program and was then reduced to 30 days and kept constant afterwards. A volume of $700 \mathrm{ml}$ was wasted from the digesters, three times per week, to achieve the average HRT of 30 days. The digesters were batch fed with an equal volume of diluted waste, consisting of de-ionized water mixed with the appropriate weight of OFMSW, to achieve the target OLR of $2.4 \mathrm{gVS} / \mathrm{L} . \mathrm{d}$. The adopted HRT and design OLR, as well as the incremental feeding strategy were defined based on previous successful startup of thermophilic AD of OFMSW in the absence of acclimated inocula. ${ }^{7}$ After every feeding, the digesters' headspace was purged with nitrogen for 2 minutes to avoid oxygen contamination.

\section{Inoculation process}

Digester A was inoculated with a control seed mix consisting of anaerobic digestate (from a thermophilic lab reactor inoculated with manure and fed with OFMSW), cattle manure (from a local cattle rearing farm few hours after excretion),

This article is protected by copyright. All rights reserved. 
and WAS (from a nearby wastewater treatment plant) to provide a diverse consortium of methanogens. Digester B was inoculated with the control mix supplemented with landfill leachate (from an active solid waste landfill) and municipal waste compost (from a nearby active composting plant with an unfinished windrow reaching $\sim 60{ }^{\circ} \mathrm{C}$ ) to further improve the biodiversity of the inoculum.

The collection and addition of seeds to the digesters took 24 days. On the first day, 1,250 $\mathrm{g}$ of raw manure were introduced into the empty reactors and diluted with 4.5 L of wasted digestate. On the third day, $1 \mathrm{~L}$ of WAS was added to each digester. Both digesters were then filled with de-ionized water to reach a working capacity of 9 L. On day 9, 1.3 L of digester B was replaced with leachate, while 1.3 L of digester A was replaced with de-ionized water. On day 24, 100g of compost were added to digester $\mathrm{B}$. The temperature in the reactors was increased to $55^{\circ} \mathrm{C}$ on day 1 , without a gradual acclimation period, thus selecting real thermophiles rather than thermotolerant microogansims. ${ }^{20}$ The "seeding strategy", as referred to in the text, represents all aspects related to seeding (i.e. seed source, seed mix and frequency of seeding.

\section{Monitoring and control methods}

The temperature control was automated through a control unit connected to a built-in temperature probe and a heating blanket. Continuous $\mathrm{pH}$ reading was conducted using a submerged $\mathrm{pH}$ probe with manual adjustment (when needed) by adding $\mathrm{NaOH}(5 \mathrm{M})$ solution. Biogas measurements were taken once or twice daily, using the water displacement method for total gas generation and a dual wavelength infrared cell with reference channels (GEM-2000 monitor, Keison Products, UK) for $\mathrm{CH}_{4}$ concentration. The latter is multiplied by the total gas generation to obtain the $\mathrm{CH}_{4}$ generation rate. The specific methane yield was calculated as liter of methane generated per gram of VS fed into the system.

This article is protected by copyright. All rights reserved. 
The biochemical analysis was conducted on a weekly basis whereby a fraction of the wasted material was used to measure total and volatile solids, and total Chemical Oxygen Demand (COD). The rest was centrifuged and filtered using a $1.2 \mu \mathrm{m}$ pores filter for analysis of soluble compounds. COD (total and soluble) was determined using the modified 5220D procedure of Standard Methods for the Analysis of Water and Wastewater (APHA, AWWA and WPCF, 2012) by HACH high-range COD kit (HACH Company, Loveland, Colorado). Similarly, solid content (total, suspended, dissolved and volatile) was analyzed using Standard Methods 2540B and 2540E procedures. Partial and total alkalinities (PA and TA, respectively) were measured by titration with $\mathrm{HCl}(0.2 \mathrm{~N})$ to $\mathrm{pH}$ of 5.75 and 4.3 , respectively, and intermediate alkalinity (IA) was calculated as the difference between PA and TA. ${ }^{21}$ Total ammonia content was determined by spectrophotometry using $\mathrm{HACH}$ high-range ammonia kit (HACH Company, Loveland, Colorado). The free ammonia $\left(\mathrm{NH}_{3}\right)$ was calculated based on the $\mathrm{NH}_{3}$-to- $\mathrm{NH}_{4}{ }^{+}$relationships expressed in Equations 1 and $2:^{22}$

$$
\begin{aligned}
& N H_{3}-N=\frac{N H_{4}^{+}-N \times 10^{p H}}{K_{b} / K_{w}+10^{p H}} K_{b} / K_{w} \\
& N H_{3}-N=e^{(6344 / 273+T)}
\end{aligned}
$$

Where $K_{b} / K_{w}$ is the ratio of the ionization constant of the ammonia equilibrium equation to the ionization constant of water.

The concentrations of acetate, propionate and butyrate inside the digesters were measured, once to twice per HRT, using a gas chromatograph (Trace GC Ultra, Thermo Electron corporation) equipped with a flame ionization detector and a TR-FFAP capillary column with nitrogen carrier gas. The temperature inside the oven was initially set at $85^{\circ} \mathrm{C}$ ( 3 min hold time) and increased at a rate of $6^{\circ} \mathrm{C} / \mathrm{min}$ to a final temperature of $150{ }^{\circ} \mathrm{C}$ (1min hold time). Inlet and FID base temperatures were set to

This article is protected by copyright. All rights reserved. 
$240{ }^{\circ} \mathrm{C}$ and $220{ }^{\circ} \mathrm{C}$, respectively.

\section{Quantitative Polymerase Chain Reaction (QPCR)}

Total genomic DNA was extracted from the samples using the Power soil DNA isolation Kit (MoBio Laboratories, Inc., Carlsbad, CA) according to the manufacturer's instructions. The proportions of various methanogens, Methanobacteriales, Methanomicrobiales, Methanosaetaceae and Methanosarcinaceae, in the total methanogenic community, were determined by QPCR. Amplification was performed in a $25-\mu 1$ reaction volume containing $12.5 \mu 1$ of $2 \times$ iQ Supermix, $0.5 \mu \mathrm{M}$ of each primer, $0.2 \mu \mathrm{M}$ of each probe, $1 \mu \mathrm{l}$ sample DNA, and RNase-free sterile water to a final volume of $25 \mu \mathrm{l}$. Amplification was performed using the CFX96 real-time PCR detection system (Bio-Rad Laboratories, Hercules, CA) with PCR conditions for methanogens described by Yu et al. ${ }^{23}$ All primers, probes and plasmid standards used in this study are listed in Table 2. For standard clone preparation, the PCR amplicons were first cloned into a TOPO cloning vector (pCR 2.1-Topo vector, Invitrogen, Carlsbad, CA) according to the manufacturer's protocol. Plasmids from transformed cells were extracted by the PureYield ${ }^{\mathrm{TM}}$ Plasmid Miniprep System (Promega, Madison, WI). Copy numbers per microliter were calculated from the concentration of extracted plasmid DNA using the known sequences of the vector and inserts. The standard template DNA was diluted in series and the $\mathrm{C}_{\mathrm{t}}$ values for each dilution were plotted against the 16S rRNA gene copy number of each dilution to construct the standard curve. All QPCR assays were performed in triplicate. QPCR assays with $\mathrm{C}_{\mathrm{t}}$ values over 40 were considered negative. For each QPCR run, a negative (no template) control was used to test for false positives or contamination.

Insert Table 2: QPCR primers and probes used to quantify various methanogenic archaea

This article is protected by copyright. All rights reserved. 


\section{RESULTS AND DISCUSSION}

\section{Seeds Selection and Characterization}

Both acetotrophic methanogens (converting acetate to $\mathrm{CH}_{4}$ ) and hydrogenotrophic methanogens (converting $\mathrm{H}_{2} / \mathrm{CO}_{2}$ into $\mathrm{CH}_{4}$ ) are essential for $\mathrm{AD}$ systems. While acetotrophs often dominate, hydrogenotrophic methanogens are known to be more tolerant to acid accumulation and favored under thermophilic conditions. ${ }^{18}$ Acetotrophic methanogenesis is achieved by members of the family Methanosarcinaceae (with higher growth rate) at high acetate concentrations, or Methanosaetaceae (with higher substrate affinity) at low acetate concentrations $(<1$ mmol). ${ }^{19}$ Therefore, initial seeds were selected to provide both acetotrophic families. Similarly, inocula containing both hydrogenotrophic orders (Methanobacteriales and Methanomicrobiales) were included in the seeding mixes. In addition to enriching the methanogenic component, combining several seeding sources increases the chances of an overall diverse microbial community that offers the advantage of better and faster degradation of organic compounds due to syntrophic interactions where the waste of one species is needed by other species. ${ }^{9}$

Five types of seeding sources were tested using QPCR: thermophilic digestate, cattle manure, WAS, compost and leachate. The digestate and manure exhibited a very close methanogenic composition. They were both dominated by the Methanosarcinaceae family ( $95 \%$ and $85 \%$, respectively), of the acetotrophic Methanosarcinales order, with a limited presence of the hydrogenotrophic Methanobacteriales order (5\% and 15\%, respectively) (Table 3). The observed similarity may be due to drawing the digestate from a digester that was inoculated with manure only. The control seed mix consisted of manure, digestate, and WAS. The latter provided a source of Methanomicrobiales (50\%) and Methanosaetaceae (46\%), both 
absent in the digestate and manure.

The compost (78\% acetotrophs) and leachate ( $94 \%$ hydrogenotrophs, mainly Methanomicrobiales) were added to the control seed mix components with the aim to improve the seed mix by enhancing the methanogenic diversity of the inoculum through an additional source of hydrogenotrophic orders and the less abundant acetotrophic family (Methanosaetaceae). While similar hydrogenotrophic dominance in landfill leachate have been reported, ${ }^{13,14}$ the compost used in this experiment was dominated by acetotrophs, in contrast to previously reported hydrogenotrophic dominance in domestic waste compost. ${ }^{11}$

\section{Insert Table 3: Relative abundance of various methanogenic orders in the selected seeds}

\section{Startup}

During the seeding period, feeding was varied depending on the performance of the digesters (attempting to maintain methane generation while avoiding VFA buildup), resulting in average biogas generation rates of $1.15 \mathrm{~L} / \mathrm{L} . \mathrm{d}$ and $0.99 \mathrm{~L} / \mathrm{L} . \mathrm{d}$ in digesters A and $\mathrm{B}$, respectively. At the end of the seeding period (day 26), incremental loading was initiated by gradually increasing the weight of the waste in the feed, while keeping a constant influent and effluent volume to maintain a constant HRT. Accordingly, the OLR was increased gradually to reach a design rate of $2.4 \mathrm{gVS} / \mathrm{L} . \mathrm{d}$ (Figure 1).Upon initiation of incremental loading, the weekly average biogas volume dropped because of the low initial OLR $(0.8 \mathrm{gVS} / \mathrm{L} . \mathrm{d})$ and increased again with organic loading to stabilize at $\sim 1.66 \mathrm{~L} / \mathrm{L} . \mathrm{d}$ in A and 1.60 L/L.d in B at OLR $=2.4 \mathrm{gVS} / \mathrm{L} . \mathrm{d}$ (Figure 1).

\section{Insert Figure 1. Loading conditions, pH, and weekly average gas generation}

On the other hand, $\mathrm{pH}$ increased during the seeding period, presumably because of enhanced acid degradation with the progressive addition of seeds. During the

This article is protected by copyright. All rights reserved. 
incremental loading period, the $\mathrm{pH}$ decreased to $\sim 7.2$ then gradually increased, indicating the progressive acclimation of the microbial flora, until stabilizing at $\sim 7.6$ in both digesters. Note that the rising slope of the $\mathrm{pH}$ graph in digester B started about 30 days prior to digester $\mathrm{A}$; and upon reaching steady state, the $\mathrm{pH}$ in $\mathrm{B}$ was always slightly higher than that in digester A (Figure 1) which can be attributed to faster microbial acclimation in digester B during startup and lower acid generation during steady-state (see Figure 4). The target OLR (2.4gVS/1.d) was constantly applied over the last 115 days ( $\sim 4 \mathrm{HRT})$ during which the $\mathrm{pH}$ was stable in both digesters and the variation between two consecutive gas readings was $<10 \%(0.1$ to $6.9 \%$ in $\mathrm{A}$ and 0.2 to $9.8 \%$ in B), indicating a steady-state operation. ${ }^{24,25}$

In general, both digesters were successfully started in 3.6 months, from day 26 (time needed to acquire all seeds) to 135 (initiation of stable feeding), with final OLR $=$ $2.4 \mathrm{gVS} / \mathrm{L} . \mathrm{d}$ and HRT $=30$ days. In thermophilic digesters with a seed that is not acclimated to high temperatures and to the OFMSW substrate, the startup can take longer. ${ }^{26}$ In fact, the start-up of a similar digester, inoculated only with manure, necessitated 5.6 months to reach the target OLR of $2.5 \mathrm{gVS} / \mathrm{L} . \mathrm{d} .{ }^{7}$

\section{Microbial analysis}

In both digesters, the methanogenic community was dominated by acetotrophic methanogens (Figure 2), consisting almost solely (100\%) of Methanosarcinaceae. The hydrogenotrophic methanogens consisted mainly (95 - 100\%) of Methanobacteriales, typical of similar thermophilic anaerobic digesters. ${ }^{27,28}$ Methanomicrobiales were present at trace levels $(<1 \%)$ where as Methanosaetaceae were absent, even though both were present in the initial seeds. The addition of WAS $(50 \%$ Methanomicrobiales and 46\% Methanosaetaceae) and leachate (94\% Methanomicrobiales) did not contribute to their abundance in the digesters suggesting that the operating conditions

This article is protected by copyright. All rights reserved. 
and substrate composition are not favorable for the proliferation of these methanogens.

At the onset of the experiment, acetotrophic methanogens had a high relative abundance $(>80 \%)$ compared to hydrogenotrophic methanogens $(<20 \%)$. With time, the relative abundance of hydrogenotrophic methanogens increased under acetotrophic dominance. At the end of the experiment (day 250), the difference decreased to reach about 60 -to- $40 \%$ and 70 -to-30\% acetotrophs-to-hydrogenotrophs, in digesters $\mathrm{A}$ and $\mathrm{B}$, respectively (Figure 2). Accordingly, the addition of leachate and compost seems to have shifted the microbial community by $\sim 10 \%$ toward acetotrophs. This observation differs from reported findings in mesophilic systems, where the addition of hydrogenotroph-rich compost resulted, at the end of the experiment, in a shift toward hydrogenotrophic methanogens. ${ }^{12}$ However, in this study, the hydrogenotroph-rich leachate, added to digester B, was $94 \%$ dominated by the Methanomicrobiales order, which did not proliferate, presumably because of selective operational conditions and substrate composition.

\section{Insert Figure 2. Relative abundance of hydrogentrophs and acetotrophs}

\section{COD, solids and ammonia}

In the early stages, soluble COD concentrations in digester B were higher than those in digester A because of the additional seeding material. However, during incremental loading (i.e. days 50 to 130 ) the soluble COD was significantly higher $(\mathrm{P}=$ 0.0003 , student's t-test $)$ in $A(3.17 \pm 0.95 \mathrm{~g} / \mathrm{L})$ than $\mathrm{B}(2.03 \pm 0.55 \mathrm{~g} / \mathrm{L})$ implying enhanced degradation of soluble compounds in B (Figure 3.a). However, the total COD was comparable in both digesters (average $=17 \mathrm{~g} / \mathrm{L}$ ), which could be attributed to the presence of recalcitrant and inorganic material from the compost and/or leachate seed in digester B. During sieving of the compost seed, prior to addition to the digester, small plastic, soil and glass particles were present and removed to the extent visually

This article is protected by copyright. All rights reserved. 
discernible. The total COD in digester B decreased below that of digester A with progressive washout of the initial seed material (Figure 3.b).

Under steady-state operations, the average total COD in digester B was $22 \mathrm{~g} / \mathrm{L}$ (of which $3.6 \mathrm{~g} / \mathrm{L}$ were soluble), compared to $28 \mathrm{~g} / \mathrm{L}(4.4 \mathrm{~g} / \mathrm{L}$ soluble) in digester A. The COD removal in A and B was $74 \%$ and $76 \%$, respectively. The addition of leachate has reportedly improved the hydrolysis of cellulose, ${ }^{15}$ which reportedly constitutes $9-10 \%$ of food waste. ${ }^{29,30}$ While the slight improvement in COD removal efficiency in digester B (76\% vs. $74 \%$ in A) may be attributed to improved cellulose hydrolysis, the difference is within the margin of error of the measurements and the results can be considered comparable.

Similarly, the Total Solids (TS) was initially higher in digester B because of additional solids from the compost and leachate seeds; but eventually converged in both digesters and stabilized at an average of $1.6 \%$, indicating similar TS removal in both digesters during steady state (Figure 3.c). Concurrently, volatile suspended solids (VSS), commonly used as an indicator of total microbial abundance in anaerobic reactors, ${ }^{31}$ became similar in both digesters with an average of $1.1 \%$ at steady state (Figure 3.c). However, the $\mathrm{pH}$, which decreased in both digesters upon initiation of incremental loading, increased again at a faster rate, and at an earlier time, in B (Figure 1), indicating a faster microbial acclimation.

Last, while total and free ammonia concentrations in both digesters were below reported inhibitory levels of $1,200-4,900 \mathrm{mg} / \mathrm{L}^{20}$ and $680-690 \mathrm{mg} / \mathrm{L}^{32}$, respectively, total ammonia was $23 \%$ higher in digester A, with an average of $822 \mathrm{mg} / \mathrm{L}(81 \mathrm{mg} / \mathrm{L}$ free ammonia) compared to $667 \mathrm{mg} / \mathrm{L}$ (68 mg/L free ammonia) in digester B (Figure 3.d).

Insert Figure 3. COD, solids, and ammonia concentrations

This article is protected by copyright. All rights reserved. 


\section{Alkalinity and VFAs}

Initially, VFAs were higher in digester B (1,545 mg HAc/L in B vs. $651 \mathrm{mg}$ HAc/L in A), possibly because of the degradation of the additional inocula (compost and leachate). With progressive washout of the initial seeding material, the VFAs decreased and converged in both digesters to 268 and $271 \mathrm{mg} \mathrm{HAc} / \mathrm{L}$ in $\mathrm{A}$ and $\mathrm{B}$, respectively, almost evenly split between acetate and propionate (Figure 4.a). At steady-state, digester B maintained a fairly stable VFA concentration $(229 \pm 84 \mathrm{mg} / \mathrm{L})$ composed of acetate $(147 \pm 50 \mathrm{mg} / \mathrm{L})$ and propionate $(92 \pm 63 \mathrm{mg} / \mathrm{L})$. In contrast, the VFA level was variable in digester A $(510 \pm 205 \mathrm{mg} / \mathrm{L})$, and mostly dominated by propionate $(423 \pm 266 \mathrm{mg} / \mathrm{L})$. Based on t-test, the propionate concentrations in digester A were significantly higher than digester $\mathrm{B}(\mathrm{P}=0.035$, student's $\mathrm{t}$-test $)$.

As such, average propionate-to-acetate ratio (3.4 in A vs. 1.9 in B) and VFA-toalkalinity $(\alpha)$ ratio $(0.11$ in A vs. 0.04 in B) were considerably lower in B. The $\alpha$-ratio reflects the balance, or the lack of it, between the potential cause of $\mathrm{pH}$ drop (VFA accumulation) and the buffering capacity of the system (alkalinity) and is commonly

used to monitor the system's stability. ${ }^{33}$ The lower $\alpha$ ratio and hence improved stability in digester B, can be attributed to the addition of compost and leachate. Stability is a common concern in thermophilic AD of OFMSW whereby meta-stable, rather than fully-stable, conditions often occur with vulnerability to operational disturbances. ${ }^{33}$ Note that butyrate was detected only toward the end of the experiment with an average of $21 \mathrm{mg} / \mathrm{L}$ in $\mathrm{A}$, compared to $8 \mathrm{mg} / \mathrm{L}$ in B (Figure $4 . \mathrm{a}$ ).

The Alkalinity was comparable in both digesters and started at high concentrations initially $(\sim 9,000 \mathrm{mg} / \mathrm{L}$ in $\mathrm{A}$ and $8,000 \mathrm{mg} / \mathrm{L}$ in B), then leveled out to an average of $\sim 5,000 \mathrm{mg} / \mathrm{L}$ in both digesters (Figure 4.b). However, the intermediate-topartial alkalinity ratio (IA/PA) and the intermediate-to-total alkalinity ratio (IA/TA)

This article is protected by copyright. All rights reserved. 
were higher in digester A during startup. The IA/PA and IA/TA ratios are often considered as alternative process stability indicators in thermophilic digesters ${ }^{21}$ with process failure thresholds of 0.9 and 0.5 , respectively. While IA/PA and IA/TA in digester B remained below 0.6 and 0.4 , respectively, they reached 1.0 and 0.5 in digester $\mathrm{A}$ by the end of the incremental loading (Figure 4.c), equally implying that digester B was more stable during startup.

\section{Figure 4. Volatile fatty acids and alkalinity concentrations}

\section{BIOGAS GENERATION}

Throughout the experimental program, both digesters were fed every Monday, Wednesday and Friday and methane generation was reported accordingly (Figure 5). Thus, the oscillations in Figure 5 reflect the weekly pattern, whereby methane generation is highest on Mondays (corresponding to the peaks) as a result of an additional resting day on Sunday where VFAs that accumulated during the week were degraded, resulting in peaks of biogas yield with a concomitant increase in $\mathrm{pH}$.

During startup, methane generation was slightly (6\%) higher in digester B (366 $\mathrm{mL} / \mathrm{gVS}$ compared to $344 \mathrm{~mL} / \mathrm{gVS}$ in digester A), similar to reported observations by Neumann and Scherer ${ }^{12}$ upon adding compost. However, this difference remains within the margin of error of the measurements and the results can be considered comparable. Similarly, during steady-state, the biogas generation and methane specific yield were close in both digesters, despite differences in the methanogenic composition. Specific methane yields during steady-state reached 360 and $365 \mathrm{~L} \mathrm{CH}_{4} / \mathrm{gVS}$. in A and B, respectively (Figure 5), which are within reported ranges (300-400 $\mathrm{L} \mathrm{CH}_{4} / \mathrm{gVS} . \mathrm{d}$ ) for thermophilic digesters treating various types of OFMSW at OLR $\sim 2.8$ g VS/L.d. ${ }^{35}$

Insert Figure 5. Weekly average of methane generation

This article is protected by copyright. All rights reserved. 


\section{Seed Impact}

Hydrogenotrophs and acetotrophs were dominated by Methanobacteriales and Methanosarcinaceae, respectively. Methanomicrobiales and Methanosaetaceae were almost absent in the digesters, despite their considerable relative abundance in both seeds. Accordingly, the seed does not seem to favor a specific methanogenic group. While seeds are reported to have a significant impact on microbial diversity and composition during and after the startup phase, ${ }^{36,37}$ operational conditions (digester type, temperature, mixing, OLR and/or HRT) may cause shifts in microbial communities, thus attenuate the impact of the initial seed. ${ }^{38,39}$ Also, the elapsed time between the additions of different seeds allowed for microbial acclimation in both digesters, leading to closely similar microbial compositions. ${ }^{40}$ Furthermore, the addition of compost ( $78 \%$ acetotrophs) and leachate ( $94 \%$ hydrogenotrophs) did not balance the increase in both types of methanogens in digester B. The hydrogenotrophic methanogens in the leachate consisted almost only of Methanomicrobiales, which was not favored under the experimental conditions of this study. On average, the relative abundance ratio of acetotrophs-to-hydrogenotrophs under steady state conditions was 66-to-34\% in digester A and 76-to- $24 \%$ in digester B, implying a $10 \%$ shift toward acetoclastic pathways in $\mathrm{B}$.

Most notably, digester B that was enriched with a mix seed of leachate and compost exhibited enhanced propionate degradation and lower VFA-to-alkalinity $(\alpha)$ ratio (a stability indicator). Also, it demonstrated a faster $\mathrm{pH}$ stabilization and reduced ammonia levels. Improved propionate degradation in digester B could be due to the improved inoculation strategy and presence of major propionate oxidizers, such as Syntrophobacter and Smithella, that are lacking in manure and manure-seeded digestate. ${ }^{28}$ Further examination of the bacterial composition and diversity may 
ascertain this postulation.

\section{CONCLUSION}

Successful performance of thermophilic anaerobic digesters was attained with a designed mix of non-acclimated seeds based on their methanogen composition, using Quantitative Polymerase Chain Reaction (QPCR) of 16S rRNA gene, to achieve high abundance and diversity of methanogens. Enrichment of digester B with additional seeds, namely leachate and compost, induced a faster acclimation of the microbial flora, better degradation of soluble compounds, enhanced stability manifested by a lower VFA concentration ( $510 \mathrm{mg} / \mathrm{L}$ in A vs. $232 \mathrm{mg} / \mathrm{L}$ in B), mainly propionate, and an increased buffering capacity ( $\alpha$-ratio of 0.11 in A vs. 0.04 in B). The relative abundance of acetotrophs was $10 \%$ higher in digester B compared to digester A.

\section{ACKNOWLEDGEMENTS}

This study was supported by the National Council for Scientific Research Lebanon, and the Masri Institute of Energy and Natural Resources at the American University of Beirut. The experimental setup was obtained through a grant from the US Agency for International Development. Special thanks are extended to Mr. Khaled Salam for his assistance in performing the QPCR analysis.

\section{REFERENCES}

[1] Cordoba V, Fernandez M and Santalla E, The effect of different inoculums on anaerobic digestion of swine wastewater. J Environ Chem Eng 4:115-122 (2016).

[2] Costa JC, Oliveira JV and Alves MM, Response surface design to study the influence of inoculums, particle size and inoculums to substrate ratio on the methane production from Ulex sp. Renew Energ 96:1071-1077 (2016).

This article is protected by copyright. All rights reserved. 
[3] Moset V, Al-Zohairi N and Moller H, The impact of inoculums source, inoculums to substrate ratio and sample preservation on methane potential from different substrates. Biomass Bioener 83:474-482 (2015).

[4] Forster-Carneiro T, Pe'rez M, Romero LI and Sales D, Dry-thermophilic anaerobic digestion of organic fraction of the municipal solid waste: Focusing on the inoculum sources. Bioresour Technol 98:3195-3203 (2007).

[5] Gu Y, Chen X, Liu Z, Shou, X and Zhang Y, Effect of inoculums sources on the anaerobic digestion of rice straw. Bioresour Technol 158:149-155 (2014).

[6] Hidalgo D and Martin-Marroquin J, Effects of inoculums source and co-digestion strategies on anaerobic digestion of residues generated in the treatment of waste vegetable oils. J Environ Manage 142:17-22 (2014).

[7] Ghanimeh S, Saikaly P and El-Fadel M, Mixing effect on thermophilic anaerobic digestion of source-sorted organic fraction of municipal solid waste. Bioresour Technol 117:63-71 (2012).

[8] Poggi-Varaldo HM, Valdes L, Esparza-Garcia F and Fernandez-Villagomez G, Solid substrate anaerobic co-digestion of paper mill sludge, biosolids, and municipal solid waste. Water Sci Technol 35:197-204 (1997).

[9] Islas-Espinoza M, de las Heras A, Vazquez-Chagoyan JC and Salem AZM, Anaerobic cometabolism of fruit and vegetable wastes using mammalian fecal inoculums: Fast assessment of biomethane production. J Clean Prod 141:14111418 (2017).

[10] Jäckel U, Thummes K and Kämpfer P, Thermophilic methane production and

This article is protected by copyright. All rights reserved. 
oxidation in compost. FEMS Microbiol Ecol 52:175-184 (2005).

[11] Thummes K, Schafer J, Kämpfer P and Jäckel U, Thermophilic methanogenic Archea in compost material: Occurrence, persistence and possible mechanisms for their distribution to other environments. Syst Appl Microbiol 30:634-643 (2007).

[12] Neumann L and Scherer P, Impact of bioaugmentation by compost on the performance and ecology of an anaerobic digester fed with energy crops. Bioresour Technol 102:2931-2935 (2011).

[13] Huang LN, Zhu S, Zhou H and Qu LH, Characterization of methanogenic Archaea in the leachate of a closed municipal solid waste landfill. FEMS Microbiol Lett 46:171-177 (2003).

[14] Chen AC, Imachi H, Sekiguchi Y, Ohashi A and Harada H, Archeal community compositions at different depths (up to $30 \mathrm{~m}$ ) of a municipal solid waste landfill in Taiwan as revealed by 16S rDNA cloning analyses. Biotechnol Lett 25:719-724 (2003).

[15] Song H and Clarke W, Cellulose hydrolysis by a methanogenic culture enriched from landfill waste in a semi-continuous reactor. Bioresour Technol 100:1268$1273(2009)$.

[16] Pellera F-M and Gidarakos E, Effect of substrate to inoculums ratio and inoculums type on the biochemical methane potential of solid agroindustrial waste. J Environ Chem Eng 4:3217-3229 (2016).

[17] Ghanimeh S, El-Fadel M and Saikaly P, Improving the stability of thermophilic anaerobic digesters treating SS-OFMSW through enrichment with compost and

This article is protected by copyright. All rights reserved. 
leachate seeds. Bioresour Technol 131:53-59 (2013).

[18] Demirel B and Scherer P, The roles of acetotrophic and hydrogenotrophic methanogens during anaerobic conversion of biomass to methane: A review. Rev Environ Sci Biotechnol 7:173-190 (2008).

[19] Lee C, Kim J, Hwang K, O’Flaherty V and Hwang S, Quantitative analysis of methanogenic community dynamics in three anaerobic batch digesters treating different wastewaters. Water Res 43:157-165 (2009).

[20] El-Fadel M, Saikaly P and Ghanimeh S, Startup and stability of thermophilic anaerobic digestion of OFMSW. Crit Rev Env Sci \& Tech 43:2685-2721 (2013).

[21] Ferrer I, Vazquez F and Font X, Long term operation of a thermophilic anaerobic reactor: Process stability and efficiency at decreasing sludge retention time. Bioresour Technol 101:2972-2980 (2010).

[22] Anthonisen AC, Loehr RC, Prakasam TBS and Srinath EG, Inhibition of nitrification by ammonia and nitrous acid. $J$ Water Pollut Cont Fed 48:835-849 (1976).

[23] Yu Y, Lee C, Kim J and Hwang S, Group-specific primer and probe sets to detect methanogenic communities using quantitative real-time polymerase chain reaction. Biotechnol \& Bioeng 89:670-679 (2005).

[24] Karim K, Klasson KT, Hoffmann R, Drescher S, DePaoli DW and Al-Dahhan MH, Anaerobic digestion of animal waste: Effect of mixing. Bioresour Technol 96:1607-1612 (2005).

This article is protected by copyright. All rights reserved. 
[25] Vartak DR, Engler CR, McFarland MJ and Ricke SC, Attached-film media performance in psychrophilic anaerobic treatment of dairy cattle wastewater. Bioresour Technol 62:79-84 (1997).

[26] Fdéz-Güelfo LA, Álvarez-Gallego C, Sales Márquez D and Romero García LI, Start-up of thermophilic-dry anaerobic digestion of OFMSW using adapted modified SEBAC inoculums. Bioresour Technol 101:9031-9039 (2010).

[27] Krakat N, Westphal A, Schmidt S and Scherer P, Anaerobic digestion of renewable biomass - thermophilic temperature governs population dynamics of methanogens. Appl Environ Microbiol 76:1842-1850 (2010).

[28] Ghanimeh S, Saikaly P, Li D and El-Fadel M, Population dynamics during startup of thermophilic anaerobic digesters: The mixing factor. Waste Manage 33:22112218 (2013).

[29] Schievano A, D’Imporzano G, Malagutti L, Fragali E, Ruboni G and Adani F, Evaluating inhibition conditions in high-solids anaerobic digestion of organic fraction of municipal solid waste. Bioresour Technol 101:5728-5732 (2010).

[30] Bouallagui H, Touhami Y, BenCheikh R and Hamdi M, Bioreactor performance in anaerobic digestion of fruit and vegetable wastes. Process Biochem 40:989-995 (2005).

[31] Wu S-Y, Hung C-H, Lin C-Y, Lin P-J, Lee K-S, Lin C-N, Chang F-Y and Chang J-S, HRT-dependent hydrogen production and bacterial community structure of mixed anaerobic microflora in suspended, granular and immobilized sludge systems using glucose as the carbon substrate. Int J Hydrogen Energ 33:15421549 (2008).

This article is protected by copyright. All rights reserved. 
[32] Gallert C and Winter J, Mesophilic and thermophilic anaerobic digestion of source-sorted organic wastes: Effect of ammonia. Appl Miocrobiol Biot 48:405410 (1997).

[33] Poggi-Varaldo HM and Oleszkiewicz JA, Anaerobic co-composting of municipal solid waste and waste sludge at high total solids levels. Environ Technol 13:409421 (1992).

[34] Yirong C, Banks CJ and Heaven S, Volatile fatty acid accumulation in thermophilic anaerobic digestion of food waste, Int. IWA-Symposium on Anaerobic Digestion of Solid Waste and Energy Crops, Vienna, Austria, Aug28-Sep1 (2014).

[35] Davidsson A, Gruvberger C, Christensen T, Hansen TL and Jansen JC, Methane yield in source-sorted organic fraction of municipal solid waste, Waste Manage. 27:406-414 (2007).

[36] Pandey P, Ndegwa P, Soupir M, Alldredge R and Pitts M, Efficacies of inocula on the startup of anaerobic reactors treating dairy manure under stirred and unstirred conditions. Biomass Bioenerg 35:2705-2720 (2011).

[37] Cresson R, Dabert P and Bernet N, Microbiology and performance of a methanogenic biofilm reactor during the start-up period. J Appl Microbiol 106:863-873 (2009).

[38] Chelliapan S, Wilby T, Zir A and Sallis PJ, Influence of organic loading on the performance and microbial community structure of an anaerobic stage reactor treating pharmaceutical wastewater. Desalination 271:257-264 (2011).

This article is protected by copyright. All rights reserved. 
[39] Duan L, Moreno-Andrade I, Huan C-L, Xia S and Hermanowicz SW, Effects of short solids retention time on microbial community in a membrane bioreactor. Bioresour Technol 100:3489-3496 (2009).

[40] Bertin L, Bettini C, Zanaroli G, Fraraccio S, Negroni A and Fava F, Acclimation of an anaerobic consortium capable of effective biomethanization of mechanicallysorted organic fraction of municipal solid waste through a semi-continuous enrichment procedure. J Chem Technol Biotechnol 87:1312-1319 (2012).

This article is protected by copyright. All rights reserved. 


\section{List of Tables}

Table 1. Feed characteristics

Table 2. QPCR primers and probes used to quantify various methanogenic archaea

Table 3. Relative abundance of various methanogenic orders in the selected seeds

\section{List of Figures}

Figure 1. Loading conditions, $\mathrm{pH}$, and weekly average gas generation

Figure 2. Relative abundance of hydrogentrophs and acetotrophs

Figure 3. COD, solids, and ammonia concentrations

Figure 4. Volatile fatty acids and alkalinity concentrations

Figure 5 . Weekly average of methane generation

This article is protected by copyright. All rights reserved. 
Table 1. Feed characteristics

\begin{tabular}{|c|c|c|}
\hline Parameter & Value & Unit \\
\hline \multicolumn{3}{|l|}{ Particulates $^{1}$} \\
\hline TS & 29.3 & $\%$ \\
\hline VS & 95.5 & $\% \mathrm{TS}$ \\
\hline $\mathrm{COD}_{\text {Total }}$ & 467.5 & $\mathrm{~g} / \mathrm{L}$ \\
\hline Carbon $^{2}$ & 41.8 & $\%$ \\
\hline Total Organic Carbon ${ }^{2}$ & 37.8 & $\%$ \\
\hline Nitrogen $^{2}$ & 2.7 & $\%$ \\
\hline $\mathrm{C}: \mathrm{N}$ & 15 & \\
\hline Total Phosphorus & 1.7 & $\mathrm{~g} / \mathrm{Kg}$ \\
\hline \multicolumn{3}{|l|}{ Soluble compounds ${ }^{3}$} \\
\hline $\mathrm{COD}_{\text {Soluble }}$ & 14.0 & $\mathrm{~g} / \mathrm{L}$ \\
\hline $\mathrm{NO}_{3}{ }_{-} \mathrm{N}$ & 13.4 & $\mathrm{mg} / \mathrm{L}$ \\
\hline $\mathrm{NO}_{2} \mathrm{~N}$ & 0.05 & $\mathrm{mg} / \mathrm{L}$ \\
\hline $\mathrm{NH}_{3}$ & 19.0 & $\mathrm{mg} / \mathrm{L}$ \\
\hline Partial Alkalinity, $\mathrm{pH}=5.75$ & 0.0 & $\mathrm{mg} / \mathrm{L}$ \\
\hline Total Alkalinity, $\mathrm{pH}=4.3$ & 432.0 & $\mathrm{mg} / \mathrm{L}$ \\
\hline Acetate & 170.5 & $\mathrm{mg} / \mathrm{L}$ \\
\hline Propionate & 648.0 & $\mathrm{mg} / \mathrm{L}$ \\
\hline Butyrate & 37.5 & $\mathrm{mg} / \mathrm{L}$ \\
\hline \multicolumn{3}{|c|}{${ }^{2}$ Concentrations in the raw feed, i.e. prior to dilution with distilled water for feedin } \\
\hline
\end{tabular}

This article is protected by copyright. All rights reserved. 
Table 2. QPCR primers and probes used to quantify various methanogenic archaea

\begin{tabular}{|c|c|c|c|}
\hline Primer-probe & Target & Plasmid standard & Sequence 5'-3' \\
\hline MBT 857 F & \multirow[t]{3}{*}{ Methanobacteriales } & \multirow{3}{*}{$\begin{array}{l}\text { Methanobacteriumformicium } \\
\text { (EU 544028) }\end{array}$} & CGWAGGGAAG CTGTTAAGT \\
\hline MBT 1196 R & & & TACCGTCGTCCACTCCTT \\
\hline MBT 929 probe & & & AGCACCACAACGCGTGGA \\
\hline MMB 282 F & \multirow[t]{3}{*}{ Methanomicrobiales } & \multirow{3}{*}{$\begin{array}{l}\text { Methanomicrobiales KB 1-1 } \\
\text { (AN - DQ301905) }\end{array}$} & ATCGRTACGGGTTGTGGG \\
\hline MMB 832 R & & & CACCTAACGCRCATHGTTTAC \\
\hline MMB 749 probe & & & TYCGACAGTGAGGRACGAAAGCTG \\
\hline MST 702F & \multirow[t]{3}{*}{ Methanosaetaceae } & \multirow{3}{*}{$\begin{array}{l}\text { Methanosaeta KB 1-1 } \\
\text { (AY 570685) }\end{array}$} & TAATCCTYGARGGACCACCA \\
\hline MST $863 \mathrm{R}$ & & & CCTACGGCACCRACMAC \\
\hline MST 753 probe & & & ACGGCAAGGGACGAAAGCTAGG \\
\hline MSC 380F & \multirow[t]{3}{*}{ Methanosarcinaceae } & \multirow{3}{*}{$\begin{array}{l}\text { Methanosarcinathermophila } \\
\text { (M59140) }\end{array}$} & GAAACCGYGATAAGGGGA \\
\hline MSC 828R & & & TAGCGARCATCGTTTACG \\
\hline MSC 492 probe & & & TTAGCAAGGGCCGGGCAA \\
\hline
\end{tabular}

This article is protected by copyright. All rights reserved. 
Table 3. Relative abundance of various methanogenic orders in the selected seeds

\begin{tabular}{|c|c|c|c|c|c|c|}
\hline \multirow[b]{2}{*}{ Seed } & \multicolumn{6}{|c|}{ Relative abundance $^{1}(\%)$} \\
\hline & $\mathrm{MBT}^{2}$ & $\mathrm{MMB}^{2}$ & $\mathrm{MSC}^{2}$ & $\mathrm{MST}^{2}$ & Hydrogenotrophs & Acetotrophs \\
\hline Digestate & 5 & -3 & 95 & $<1$ & 5 & 95 \\
\hline Manure & 15 & - & 85 & - & 15 & 85 \\
\hline WAS & 3 & 50 & 2 & 46 & 53 & 48 \\
\hline Compost & 22 & - & 41 & 37 & 22 & 78 \\
\hline Leachate & $<1$ & 94 & 6 & $<1$ & 94 & 6 \\
\hline
\end{tabular}

${ }^{1}$ Percent of total number of methanogenic $16 \mathrm{~S}$ rRNA gene copies/ng DNA

${ }^{2}$ MBT Methanobacteriales; MMB: Methanomicrobiales; MSC: Methanosarcinaceae; MST: Methanosaetaceae

${ }^{3}$ Below the detection limit of the qPCR assays

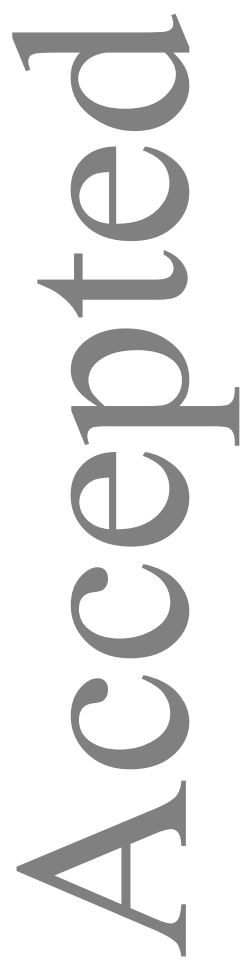

This article is protected by copyright. All rights reserved. 


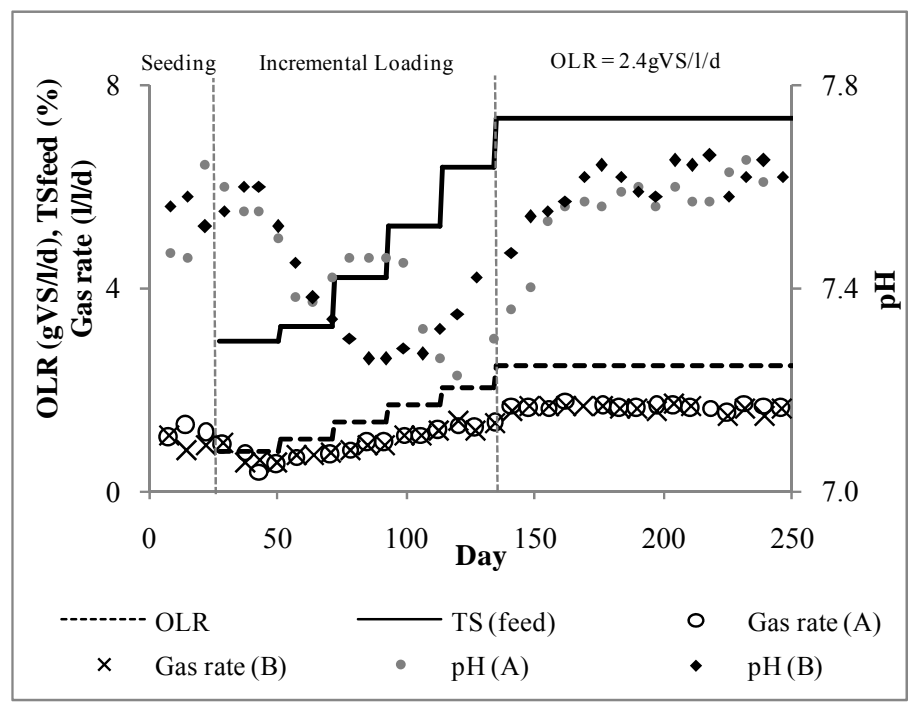

Figure 1. Loading conditions, $\mathrm{pH}$, and weekly average gas generation

This article is protected by copyright. All rights reserved. 


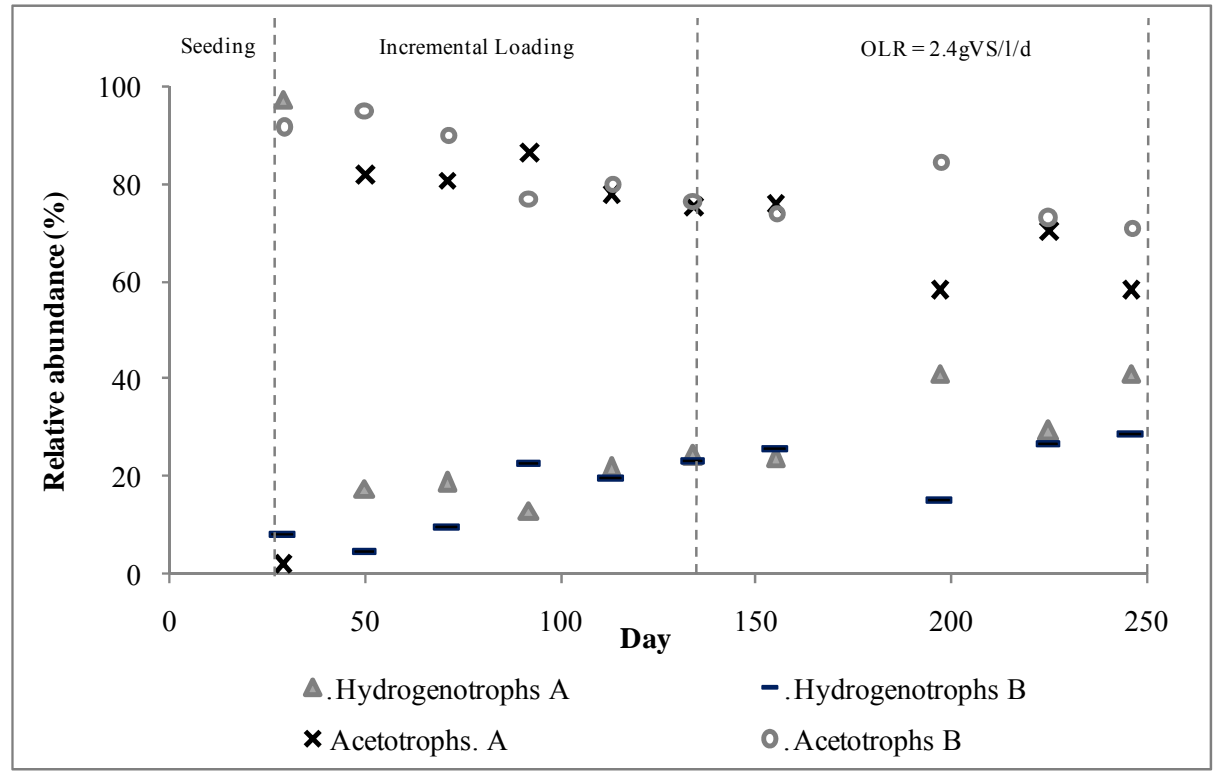

Figure 2. Relative abundance of hydrogentrophs and acetotrophs (percent of total number of methanogenic gene copies per ng extracted DNA)

This article is protected by copyright. All rights reserved. 

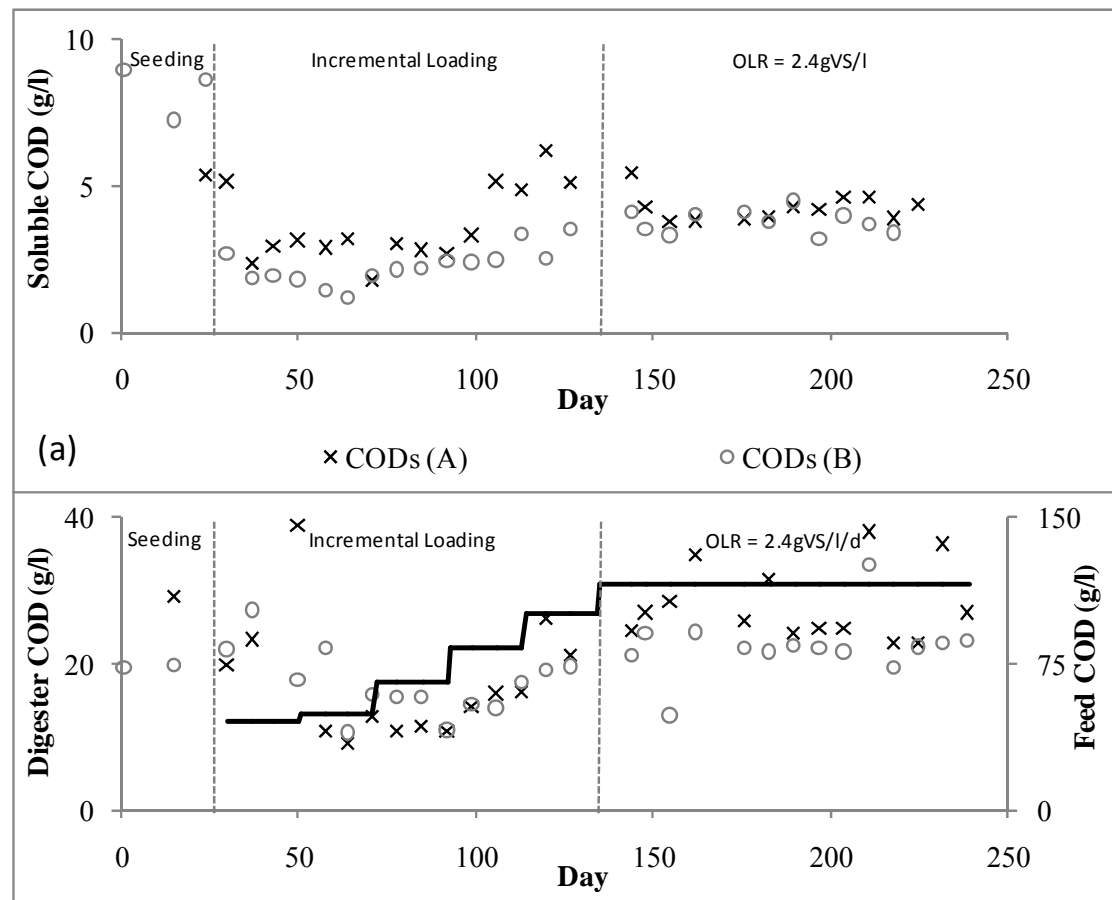

(b) $\times \operatorname{CODt}(\mathrm{A}) \quad \circ \operatorname{CODt}(\mathrm{B}) \quad \operatorname{CODt}($ feed $)$

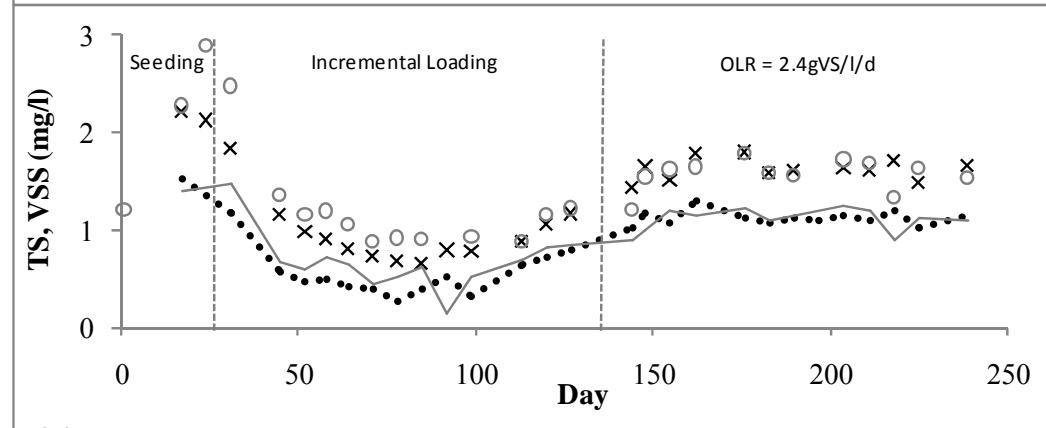

(c) $\quad \times \quad \mathrm{TS}(\mathrm{A}) \quad \circ \quad \mathrm{TS}(\mathrm{B}) \quad \cdots \cdots \cdot \operatorname{VSS}(\mathrm{A}) \quad$ VSS (B)

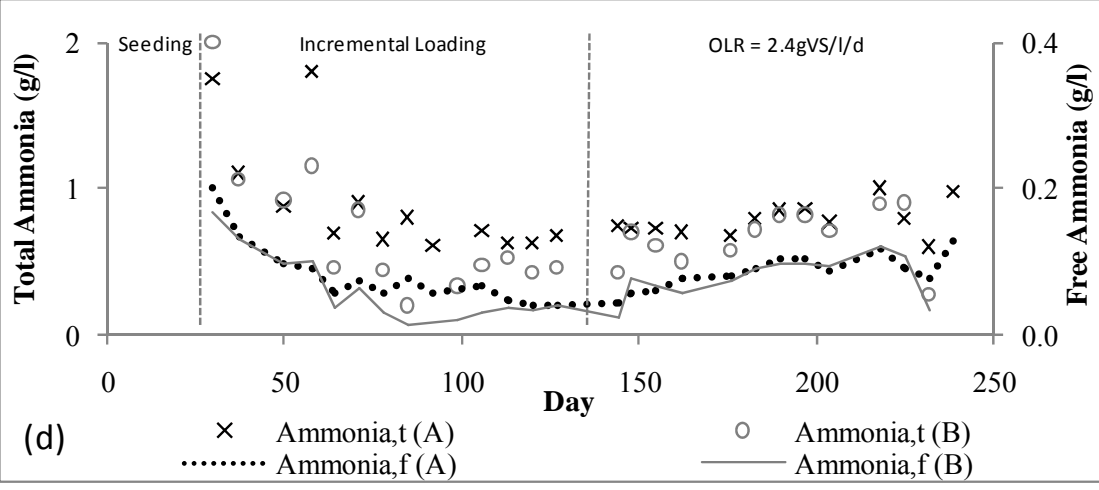

Figure 3. COD, solids, and ammonia concentrations (t: total; s: soluble; f: free)

This article is protected by copyright. All rights reserved. 

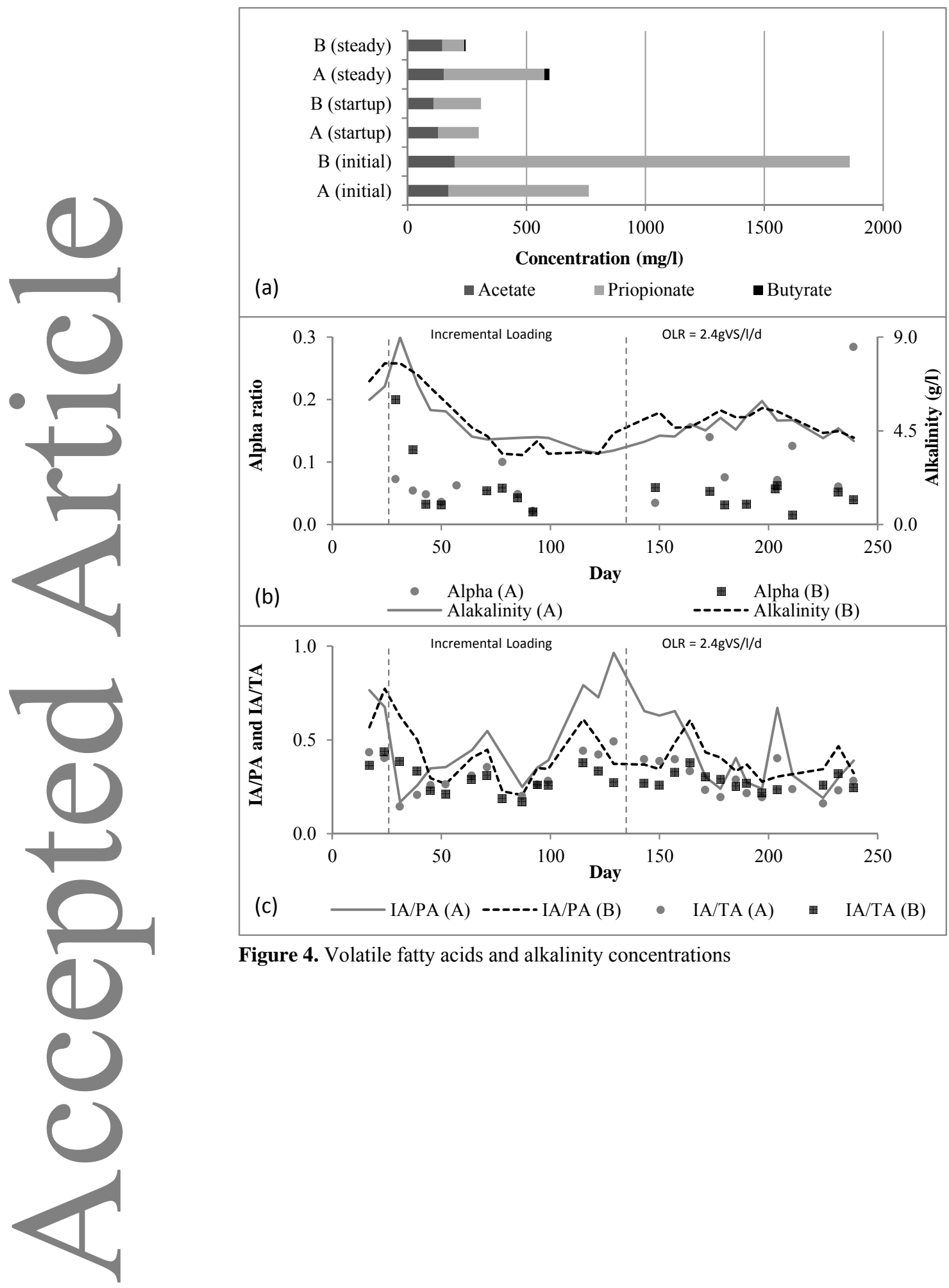

Figure 4. Volatile fatty acids and alkalinity concentrations

This article is protected by copyright. All rights reserved. 


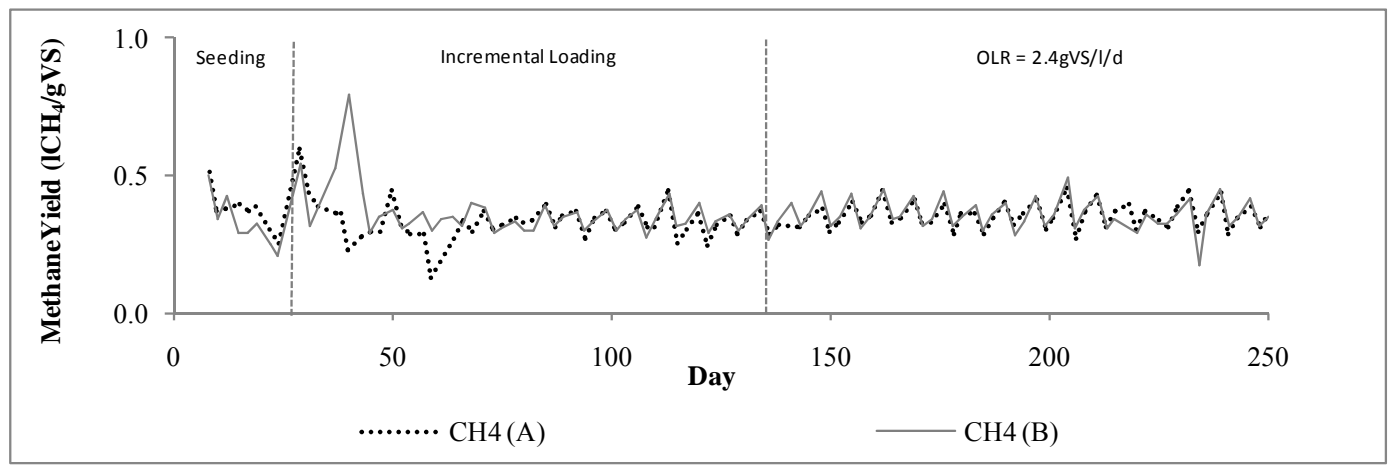

Figure 5. Weekly average of methane generation

This article is protected by copyright. All rights reserved. 